\title{
A racialização presente em telenovelas sob a perspectiva do topos
}

The racializacion in this soap-operas from the perspective of the topos

\author{
Adriana dos Reis Silva \\ PUC-Minas \\ Maysa Paulinelli \\ PUC-Minas
}

\section{Resumo}

Neste trabalho, investigaremos os aspectos racializantes presentes em determinadas cenas das telenovelas O Profeta e Duas Caras sob a ótica do topos. Este estudo se apóia nas consideraçôes acerca do topos segundo Ducrot $(1989,1999,2002)$. Assim, a noção de topos surge como um instrumento capaz de apontar o senso comum discriminatório através do lugar comum argumentativo, estabelecido pelos personagens das narrativas televisivas, assim como as possíveis soluções para desconstruir e / ou mascarar a questão racial inscrita nessas telenovelas.

Palavras-Chave

Racismo, Telenovela, Personagem negro, Topos.

\section{Abstract}

In this paper we investigate the aspects about the racism in the soap operas O Profeta and Duas Caras using the Topos theory as a reference. This study is based on the topos notion according to Ducrot $(1989,1999,2002)$. Thus, the notion of the topos that 
indicates discriminatory common sense through the argumentative commonplace established by the soap opera characters, as well as the possible solutions to deconstruct and / or to mask the racial question in these narratives produced by the media.

\section{Keywords}

Racism, Soap opera, Black character, Topos. 


\section{Introdução}

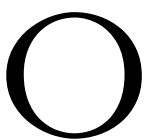

presente trabalho constitui-se de uma investigação discursiva que busca apreender como a noção de topos incide sobre a questão do preconceito racial inscrito nos registros discursivos revelados por determinadas cenas das novelas O Profeta e Duas Caras, veiculadas pela Rede Globo de Televisão.

Parece-nos que os fatos trazidos por essas tramas se constituem num bom exercício para a aplicação do conceito de topos, pois as crenças partilhadas pela comunidade brasileira em relação à racialização, neste instante, podem vir a se esclarecer. Afinal, as estratégias discursivas apresentadas por essas novelas acerca do preconceito racial / social se ratificam ou os enredos mostrados pelas narrativas em questão procuram contornar / mascarar esse fato?

\section{Apresentação do corpus}

Para construir um corpus de pesquisa, fizemos recortes nos episódios das novelas O Profeta e Duas Caras, em busca de contextos que sugerissem o preconceito racial. Voltamos nosso olhar, então, para determinados personagens negros inscritos nessas tramas. Personagens que, de certa forma, tinham uma presença marcante nas referidas narrativas, mesmo não sendo protagonistas destas.

A cada uma das cenas eleitas para este trabalho, atribuímos uma designação temática de acordo com o contexto narrativo no qual esta se inscrevia. Assim, as cenas a serem analisadas são denominadas como: "A discussão", da telenovela $O$ Profeta, e o episódio da novela Duas Caras foi chamado de "O pedido".

Essas cenas foram transcritas de maneira fiel à pronúncia realizada pelos personagens das narrativas em questão. Para realizar esse processo de transcrição, nos baseamos no trabalho de Marcushi (2005), ${ }^{1}$ entendendo ser fundamental 
para o analista saber quais são seus objetivos no momento da transcrição, para não deixar de "assinalar o que lhe convém".

A novela $O$ Profeta $^{2}$ baseada no original de Ivani Ribeiro ${ }^{3}$ de 1977 , foi produzida pela Rede Globo de Televisão no período de outubro de 2006 a maio de 2007, com 178 capítulos.

A trama se inicia na década 1940. O enredo gira em torno de um grande amor - o de Marcos e Sônia. Todavia, há também muita intriga, mistério, afinal, trata-se de um protagonista com um dom especial: o de prever o futuro.

Para esse estudo, enfatizamos uma cena em que se destaca o segmento negro dessa telenovela, composto por Dedé (personagem negra e empregada da casa de Piragibe - pai da protagonista dessa trama, Sônia) e sua filha Natália (uma mulata).

A novela Duas Caras, ${ }^{4}$ também veiculada pela Rede Globo de Televisão, exibiu 210 capítulos entre o período de outubro de 2007 a maio de 2008, e foi escrita por Aguinaldo Silva. ${ }^{5}$ Trata-se de uma narrativa em torno da relação de amor e ódio entre os personagens Adalberto Rangel e Maria Paula.

Utilizamos o mesmo procedimento de O Profeta nessa trama: focamos uma determinada cena cujo destaque é dado para certos personagens negros apresentados, tais como Sabrina (doméstica da casa da família Barreto) e o pai desta moça - Celestino (um afrodescendente).

Convém esclarecer ainda algumas peculiaridades de caráter contextual reveladas pelos personagens que focamos para esta investigação. Nesse sentido, na telenovela $O$ Profeta nos deparamos com a personagem Natália - uma menina que apresenta um comportamento intolerante em relação à mãe - uma afrodescendente. Essa personagem, Natália, é filha de Dedé, uma mulher negra, cozinheira, que trabalha na casa de Piragibe. O pai dessa menina é um homem branco, foragido da polícia, que só aparece no final da trama.

Natália apresenta uma maneira diferente de conduzir sua vida: em seu convívio social, nos espaços como a escola, ela não aceita ser filha de uma negra e ainda doméstica, termos bem frisados pela menina. Com isso, ela mente para todos dizendo ser filha de uma mulher branca e rica, além de ser neta de Piragibe.

A novela Duas Caras apresenta em seu enredo um núcleo rico composto pela família Barreto. É nesse espaço que irá emergir o relacionamento inter-racial entre Sabrina (uma negra e doméstica da casa dos Barreto) e Barretinho (rapaz branco, rico, filho do advogado Barreto). 


\section{A noção de topos}

No tocante à concepção de topos, fundamentamos nosso estudo segundo a perspectiva de Oswald Ducrot $(1989,1999,2002)$.

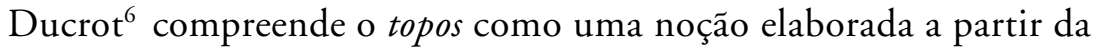
concepção aristotélica. Contudo, essa ideia está distante de abranger tudo o que Aristóteles e a Retórica clássica conferiram a esse conceito:

Se (...), o topos me diz respeito, é porque a própria estrutura das frases impõe estas condições relativas aos topoï utilizados no momento em que essas frases são proferidas no discurso e servem à produção dos encadeamentos argumentativos (DUCROT, 2002, p. 10).

Em seus estudos, o autor denomina como topos a garantia dos encadeamentos argumentativos, ou a lei de passagem entre A e C. Segundo Chabrol e Emediato (2002), em uma enunciação, o locutor oferece indicações acerca do percurso pelo qual optou, e o alocutário busca reconstruir esse caminho através das pistas fornecidas. Os topoï seriam, então, essas indicações, a possibilidade de acionar uma escolha entre os caminhos, "entre as opçôes de continuação do discurso".

Entendemos, portanto, que investigar a noção de topos nesse objeto de estudo nos parece ser uma maneira de legitimar alguns procedimentos "intuitivos em relação a certos estados de coisas", pois

Topos é um correlato entre dois conteúdos semânticos quaisquer, balanceados por um princípio de proporcionalidade que expressa a gradação entre estes dois conteúdos, de tal modo que, dado um deles, o outro pode ser pressuposto (reconstruído) por razões semânticas (topoï intrínsecos), ou por razões argumentativas (topö̈ extrínsecos) (MARI, 1997, p. 40).

Para o autor, a certeza manifesta pelos topoï possibilita dar uma forma mais exata à ideia central que conduz "toda a teoria da argumentação na língua". Essa teoria enuncia que a língua (palavras e estruturas frasais) delimita os encadeamentos argumentativos independentemente dos conteúdos de informação difundidos pelos enunciados. E mais, o lugar preciso "onde é exercida restrição", isto é, o ponto de articulação entre a língua e o discurso argumentativo evidencia-se pelos topö̈ acionados neste discurso. 
Ducrot (1989, p. 25) apreende topos como um princípio argumentativo, que apresenta as seguintes propriedades:

(i) universalidade: partilhado por uma dada comunidade linguística à qual pertença ao menos aquele realizador da démarche argumentativa, isto é, a fonte, além daquele a quem ela é apresentada, o alvo. Como exemplo, no enunciado "o tempo está bom, vamos à praia", não seria possível apresentar o calor como justificativa para ir à praia se a pessoa a quem se fala não admite também uma regra que permite transmitir a concepção de que o calor faz a praia agradável.

(ii) generalidade: o princípio deve ser considerado válido, além da situação na qual é aplicado, para um maior número de circunstâncias análogas. $\mathrm{Na}$ exemplificação anterior, o movimento argumentativo traz a ideia de que não somente no instante em que se fala, mas sempre, o calor é um fator para tornar a praia agradável.

(iii) natureza gradual: os topoï relacionam duas escalas, ou gradaçôes, que correlacionam dois predicados graduais, ou seja, quando se percorre uma das escalas, perfaz-se também a outra, e o sentido no qual se percorre uma implica certo sentido para o percurso da outra. Sendo assim, todo topos considera dois predicados $\mathrm{P}$ e $\mathrm{Q}$ cujos objetos podem satisfazer segundo o mais e o menos, ou seja, existe um sentido em dizer "a é mais P que b", ou "c é mais Q que d". Por outro lado, o topos estabelece a hipótese de mudanças na propriedade $\mathrm{P}$ (aumento / diminuição), de forma que "se no mais todas as outras condiçôes se mantêm, uma variação na propriedade $\mathrm{Q}$ - a correlação entre o sentido da variação de $\mathrm{P}$ e o sentido da variação de Q sendo sempre a mesma" (DUCROT 1989, p. 26).

Sob essa perspectiva, Ducrot (2002) considera a natureza dos topoï como gradual, apresentando, assim, uma consequência relevante para a análise do discurso:

Se o topos associa a cada um dos dois sentidos de percurso da escala antecedente um sentido de percurso determinado da escala conseqüiente, fica claro - pode-se até mesmo dizer que é logicamente necessário - que cada topos pode aparecer sob duas formas (que chamo de "formas tópicas" ou por abreviação, "FT") (DUCROT, 2002, p. 11-12). 
Logo, de acordo com esse postulado, um topos pode se apresentar sob a forma concordante, fixando suas duas escalas $\mathrm{Pe} \mathrm{Q}$ o mesmo sentido de percurso, aparecendo também sob as formas que são denominadas conversas, "+P, +Q" (trajeto ascendente de $\mathrm{P}$ está ligado a um percurso ascendente de Q); e "-P, Q" (um percurso descendente de $P$ está associado a uma trajetória descendente de Q). Por outro lado, então, também encontraríamos topos discordante, atribuindo a $\mathrm{Pe} \mathrm{Q}$ sentidos de percursos contrários, apresentando-se através das duas formas conversas: “+P, -Q" e "-P, +Q". Um topos, portanto, apresenta um princípio escalar, por exemplo, sob a forma $(+\mathrm{P},+\mathrm{Q})$, relacionando dois predicados graduais, em uma relação lógica.

Para o autor, a aplicação de uma forma tópica (doravante FT) a uma dada ocorrência pode ser denominada "apreensão argumentativa" da situação, sendo isso, então, uma

(...) função discursiva fundamental: não é possível discorrer sobre um estado de coisas sem aplicar-lhe formas tópicas. Essa função é feita de maneira evidente a cada vez que o discurso sobre o estado de coisas constitui explicitamente uma argumentação A-C (DUCROT, 2002, p.13).

Contudo, ele assevera que, no sentido do enunciado, existem indicações sobre as formas tópicas aplicáveis a essa situação. O que Ducrot (2002) denomina, no estudo sobre polifonia, de "ponto de vista dos enunciadores" agora nada mais é, segundo ele, do que a convocação de um topos por aplicação de uma FT a um objeto.

A escolha do topos e da FT se faz na existência de um encadeamento argumentativo ou ainda no momento de decisão sobre a utilização da FT para uma determinada conclusão. Então, de acordo com o autor, o locutor apresenta, nesse caso, um enunciador que se apoia sobre os precedentes e conduz a exploração da FT para um âmbito particular. Afinal, esse enunciador conclusivo se distingue daquele que aplica a FT, simplesmente pelo motivo de haver, diante do locutor, açôes discursivas distintas ocasionadas por esses enunciadores.

Para Chabrol e Emediato (2002), portanto, os topoï são formalizados pelas formas tópicas, correlacionando os predicados graduais $\mathrm{Pe} \mathrm{Q}$. E de acordo com os autores, na primeira versão sobre a teoria dos topö̈, estes eram convocados pelo exterior, decorriam do âmbito social e não estavam introduzidos na significação linguística. 
[...] a representação de um topos pelo esquema tópico (P, Q) impedia a pretensão de se evacuar, da teoria, toda referencia ao objeto, o que constrangia o desenvolvimento de uma teoria da argumentação na língua, não referencialista por definição (CHABROL; EMEDIATO, 2002, p. 300).

Se os predicados P e Q têm distinçóes semânticas, segundo os referidos autores, a relação estabelecida entre eles não é de ordem linguística, e sim algo que é evocado pelo exterior, como esquemas socioculturais, estereótipos, representaçôes sociais e discursivas.

Logo, buscando resolver essa questão, Ducrot ${ }^{7}$ e Anscombre introduzem a ideia de que os topoï aparecem no nível lexical de maneira que a significação de um lexema é considerada como um conjunto de topö̈ que autoriza a aplicação - o léxico apresenta uma estruturação tópica. Para esses autores, então, existem dois tipos de topö̈: os intrínsecos (de razões semânticas, que intervêm na significação dos vocábulos); e os extrínsecos (que regem os encadeamentos entre enunciados, com caráter sociocultural).

\section{O Profeta e Duas Caras em: o topos}

O episódio exibido em 25/12/2006, da novela O Profeta, designado como "A discussão", é a primeira cena selecionada para este estudo.

A ação narrativa se passa na casa de Piragibe. Trata-se de uma reunião informal. Inicialmente, estão na sala dessa casa, conversando: Piragibe, sua filha Sônia, o marido dela, Clóvis, a filha do primeiro casamento deste rico empresário, Analu, entre outros figurantes.

Em um determinado momento desse encontro, Clóvis se despede de todos ali presentes e vai embora com sua família (a esposa e a filha Analu). A partir de então, o diálogo centraliza-se em Dedé e Natália. Observe:

\section{Cena 1: "A discussão" - O Profeta (25/12/2006)}

(1) Dedé: Natália, quer vir comigo até o quarto? Preciso falar com você, minha filha... Natália... Eu sei por que desapareceu no dia da festa da escola... Eu sei também por que você entrou correndo quando viu Analu chegando nessa casa e se trancou neste quarto, porque você tá morrendo de medo que ela descubra a verdade, não é? Que eu sou tua mãe?! 
(2) Natália: Claro que não, mamãe... é::... Só que::... ((a voz da menina nesse instante surge de modo hesitante, trêmula.))

(3) Dedé: Não mente pra mim... Natália... Pra suas amigas você pode, mas pra mim não... Eu nunca imaginei que você podia ter vergonha de mim... Minha filha... nunca!

(4) Natália: Mas eu não tenho mamãe...

(5) Dedé: Então por que você mente sobre mim pra suas colegas? Por que você não diz pra elas que você é minha filha, hein? Fala, Natália! Por quê?

(6) Natália: Porque você é negra e empregada, mamãe!

(7) Dedé: O quê?!

(8) Natália: É isso mesmo! Porque eu já vi muita gente te tratando mal... Porque você é negra e empregada, eu não quero que façam o mesmo comigo... Eu não quero ir na festa de rico e ter que entrar pelos fundos e comer na cozinha, mamãe... Eu não quero ser igual a você... Nunca! E tem mais... Se você contar pra alguém que eu sou sua filha..., eu vou te odiar pelo resto da minha vida!

((Dedé começa a chorar e Natália, sem piedade, a deixa ali.))

Por essa cena, observa-se a personagem Dedé convidando sua filha a acompanhá-la até o quarto para ter uma conversa com a menina. Dedé descobre as mentiras da filha, e isso pode ser pressuposto ${ }^{8}$ pelo Episódio exibido em 20/12/2006, ${ }^{9}$ quando Dedé escuta Natália dizer para Analu que tem uma mãe "branquinha" que está querendo levá-la para a França.

Dedé é uma negra que trabalha na casa de Piragibe como cozinheira, e mora ali sob essa condição. No decorrer da trama, porém, essa personagem vai herdar essa propriedade de Piragibe, pois esse senhor irá falecer. Assim, de empregada da casa, Dedé passará à condição de proprietária.

Visando uma melhor caracterização dos personagens centrais desse episódio, observe o QUADRO 1 a seguir. 
QUADRO 1

Novela O profeta - Caracterização

\begin{tabular}{l|c|c|c|l}
\hline Personagens & Cor (Etnia) & Ambiente $^{10}$ & Espaço $^{11}$ & Participação \\
\hline Natália & Afro-descendente & $\begin{array}{c}\text { Classe Baixa (pobre) } \\
\text { Conduta moral duvidosa } \\
\text { Pessoa Dissimulada }\end{array}$ & $\begin{array}{c}\text { Casa de Piragibe } \\
\text { Casa de Clóvis } \\
\text { Escola }\end{array}$ & Coadjuvante \\
\hline Dedé & Negra & $\begin{array}{c}\text { Classe Baixa (pobre) } \\
\text { Boa conduta moral } \\
\text { Pessoa agradável } \\
\text { Subserviente }\end{array}$ & $\begin{array}{c}\text { Casa de Piragibe } \\
\text { Escola/ Feira } \\
\text { Casa dos amigos }\end{array}$ & Coadjuvante \\
\hline
\end{tabular}

Retomando, então, nossa proposta de análise, a qual aponta para a relação intrínseca da argumentatividade na língua, segundo Ducrot (1989), pode-se perceber que as marcas lexicais existentes nos enunciados proferidos por Dedé revelam uma forte intenção argumentativa, observe: (1): " $E u$ sei ${ }^{12}$ por que desapareceu [...] eu sei também por que você entrou correndo [...]” - a personagem quer ouvir a filha dizer, a todo custo, o porquê de a menina mentir para as amigas em relação ao fato dela ser sua mãe; (3): "Não mente pra mim [...] eu nunca imaginei que você podia ter vergonha de mim..." - Dedé ordena à menina que não minta para ela, e diz nunca ter imaginado que Natália poderia ter vergonha dela; e (5): “Então por que você mente [...] Fala, Natália! Por quê?” - Dedé esbraveja e questiona Natália sobre suas mentiras.

A argumentatividade realizada nessa cena mostra o desejo da mãe de desmascarar sua filha Natália. Nesse sentido, Ducrot (1989, p. 18) assevera que

(...) a significação de certas frases contém instruçōes que determinam a intenção argumentativa a ser atribuída a seus enunciados: a frase indica como se pode, e como não se pode argumentar a partir de seus enunciados.

Diante dessas considerações, percebe-se que o locutor representado pela personagem Dedé está afirmando fatos e, com isso, pretende, diante de seu alocutário, que neste caso apresenta-se por Natália, validar ou, pelo menos, legitimar essas conclusões. A validade conclusiva poder ser apreendida como verdade e a legitimidade como verossimilhança, pois aquela é também uma assertiva baseada em certos fatos (DUCROT, 1999, p. 4). 
Por esses aspectos, podemos verificar que a lei de passagem de A para C, isto é, o topos convocado pelos enunciados em questão é:

$[+\mathrm{P}]:$ TER CERTEZA DE UM FATO - mentiras de Natália $\rightarrow[+\mathrm{Q}]:$ PODER LEGITIMAR ESSE FATO.

Esse topos pode assumir ainda as seguintes formas tópicas:

QUADRO 2

Exemplificação de Formas Tópicas

FT:

$[+\mathrm{P}]:$ saber $\rightarrow[+\mathrm{Q}]$ : ter certeza

$[+P]:$ mentira $\rightarrow[-Q]:$ verdade

Essas FTs podem se validar por meio dos enunciados (1) e (5) de Dedé que, respectivamente, apresentam-se da seguinte forma:

(i) Discurso: “[...] Eu sei por que desapareceu no dia da festa da escola... eu sei também por que você entrou correndo quando viu Analu [...] porque você tá morrendo de medo que ela descubra a verdade, não é?"

[+P]: "Eu sei por que desapareceu no dia da festa da escola... Eu sei também por que você entrou correndo quando viu Analu [...]."

[+Q]: “[...] porque você tá morrendo de medo que ela descubra a verdade, não é?”.

$($ FT: $[+P]:$ saber $\rightarrow[+\mathrm{Q}]:$ ter certeza $)$

(ii) Discurso: "Então por que você mente sobre mim pra suas colegas, por que você não diz pra elas que você é minha filha, hein? Fala Natália?!" [+P]: "Então porque você mente sobre mim pra suas colegas, [...]."

[-Q]: "[...] porque você não diz pra elas que você é minha filha, hein? Fala, Natália!"

$($ FT: $[+P]:$ mentira $\rightarrow[-\mathrm{Q}]:$ verdade $)$

Nota-se, desde logo, que Dedé tem certeza das mentiras da filha e quer que a filha se posicione quanto a isso. Por conseguinte, as assertivas de Dedé evocam um topos que se apresenta sob uma condição intrínseca, isto é, está inscrito na significação linguística do enunciado; observe o esquema: 
TOPOS INTRÍNSECO $\rightarrow$ razões lexicais: o fato de se saber algo implica em ter certeza; e toda mentira envolve uma não verdade.

Direcionando o foco para as assertivas proferidas por Natália, percebemos que primeiro ela afirma um estado de coisas, depois se utiliza disso para conferir sua argumentação. Sob esses aspectos, o enunciado 'E' dessa personagem contém um elemento semântico 'e', que possui um valor argumentativo, que se justifica por 'r', ou seja, uma conclusão de caráter explícito (DUCROT, 1989, p. 22-23).

Logo, por intermédio dos registros discursivos dessa personagem, verificase que:

(i) nas proposições (2) e (4), Natália nega sutilmente a fala de sua mãe, mas é hesitante em seu proferimento, indicando certo receio acerca do assunto sobre o qual Dedé quer conversar com ela, conforme pode ser notado respectivamente por: "Claro que não, mamãe... é::...Só que::...”; "Mas eu não tenho, mamãe”.

(ii) em (6) a menina expõe, de maneira impetuosa, o que tanto a mãe deseja saber: o porquê de suas mentiras; Natália não aceita o fato de ter uma mãe negra e doméstica, veja: "Porque você é negra e empregada mamãe."

(iii) o enunciado (8): “[...] eu não quero ir na festa de rico e ter que entrar pelos fundo e comer na cozinha, mamãe..."; conduz a um clichê $\hat{1}^{13}$ comumente aceito pela sociedade brasileira em relação ao outro, que, neste caso, é o negro: "Porta de entrada de negro é pela cozinha". E essa é a fala de Natália, na qual ser negro significa: ter tratamento ruim, ir à festa de rico e entrar pela porta de trás, comer na cozinha, dentre outras situaçóes que possam denegrir o sujeito dito de "cor". Dessa forma, esse fato mostra que a personagem Natália assimilou as práticas sociais experienciadas por sua mãe e não quer isso para ela mesma - o preconceito dela espelha uma ideia preconcebida pela sociedade acerca da discriminação contra o negro.

Sob esses apontamentos, então, percebe-se emergir um topos advindo dos encadeamentos linguísticos proferidos pela personagem Natália: [+P]: SER NEGRA E EMPREGADA $\rightarrow[+\mathrm{Q}]:$ SER DISCRIMINADO. E as formas tópicas possíveis aqui são: 


\section{QUADRO 3}

Exemplificação de Formas Tópicas

\section{FT:}

$[+\mathrm{P}]:$ ser negro $\rightarrow[+\mathrm{Q}]:$ negar a etnia

$[+\mathrm{P}]:$ ser negro $\rightarrow[+\mathrm{Q}]:$ ser inferior

$[+\mathrm{P}]:$ ser negra e doméstica $\rightarrow[-\mathrm{Q}]:$ ter bons tratamentos

$[+\mathrm{P}]:$ ser negra e doméstica $\rightarrow[+\mathrm{Q}]:$ comer na cozinha

As FTs mostradas (entre outras) se legitimam a partir das seguintes proposiçóes:

(i) Discurso: “[...] porque você é negra e empregada, eu não quero que façam o mesmo comigo..."

$[+\mathrm{P}]$ "[...] porque você é negra e empregada $[\ldots]$ "

[+Q]: “[...] eu não quero que façam o mesmo comigo...”

$($ FT: $[+P]:$ ser negro $\rightarrow[+\mathrm{Q}]:$ ser inferior $)$

(ii) Discurso: “[...] eu não quero ir na festa de rico e ter que entrar pelos fundo e comer na cozinha, mamãe..."

$[+\mathrm{P}]:$ : $[. .$.$] eu não quero ir na festa de rico [...]”$

[-Q]: “[...] ter que entrar pelos fundo e comer na cozinha, mamãe ...”

(FT: $[+\mathrm{P}]:$ ser negro $\rightarrow[-\mathrm{Q}]:$ ter bons tratamentos), e / ou

$($ FT: $[+\mathrm{P}]:$ ser negro $\rightarrow[+\mathrm{Q}]:$ comer na cozinha)

Esse topos constitui-se, portanto, sob uma representação sociocultural e cognitiva, tratando-se de um topos extrínseco, que apresenta um teor racista, isto é, um preconceito quanto à etnia negra. Observe o esquema:

TOPOS EXTRÍNSECO $\rightarrow$ razões socioculturais: trata-se de uma implicação que não decorre do valor lexical de ser negra e empregada, e sim da circunstância do plano da enunciação, isto é, do contexto criado por essa cena.

Destarte, a personagem Natália constrói seu discurso acreditando que ser negra e doméstica é algo do qual se deve ter vergonha e, como consequência, ela não assume sua condição de afro-descendente frente à sociedade. 
Em busca de novos elementos discursivos, passamos, então, à próxima análise. O olhar, nesse momento, volta-se para a cena chamada de "O pedido", da telenovela Duas Caras. Nesse episódio, veiculado em 17/03/2008, Barretinho encontra-se com Sabrina. Ele pretende pedir a mão da moça em casamento, mas a conversa não se realiza como o rapaz esperava.

Nessa cena, nos deparamos com os interlocutores: Barretinho, um sujeito branco e advogado; Sabrina, uma negra que já trabalhou na casa dessa família e por quem Barretinho se apaixonou, além do pai dessa moça - Celestino. Observe:

\section{Cena 2: "O pedido" Duas Caras (17/03/2008)}

(1) Barretinho: Sabrina, quantas mil vezes... eu vou ter que repetir, cara? No início era isso mesmo, eu só queria dar uns pegas! Eu confesso... que eu só queria levar a empregada gostosa pra cama... Mas depois isso mudou, cara! Eu me apaixonei de verdade por você, Sabrina... Eu tô falando a verdade! Eu tô sendo sincero... Eu tô te pedindo pra ser minha mulher pro resto da vida... Quero casar contigo, de papel passado... Na igreja... Você quer prova de amor maior que essa?

(2) Sabrina: Isso não prova nada... As pessoas casam e descasam, hoje, com a maior facilidade. $\mathrm{O}$ teu problema, Barretinho, é que você não aceita perder... Eu não quis... Aí, você cismou... Ficou com a ideia fixa... E pra conseguir o que você quer... Você... É, sim... capaz de qualquer coisa!

(3) Barretinho: Não... Não... Não... Sabrina! Não... cara! Pelo amor de Deus, acredita em mim! Tô falando a verdade! A minha vida não faz o menor sentido sem você do meu lado, cara. Olha pra mim! Olha pra mim! No meu olho, me responde... Você aceita casar comigo?

((Ela não aceita o pedido do jovem. Eles discutem, relembram o tempo em que Sabrina trabalhava na casa de Barretinho, falam do casamento fracassado de Sabrina (fracasso esse decorrente do tumulto causado por Barretinho na celebração de casamento). Sabrina reclama da vida que está levando, trabalhando como doméstica na casa da tia de Barretinho, o rapaz intervem:))

(4) Barretinho: Mas é exatamente isso que eu tô te falando, Sabrina. Eu quero te dar outra vida... Casa comigo, que eu vou te dar uma vida de rainha! 
(5) Sabrina: Eu não quero uma vida de rainha do teu lado! Você tá tentando me comprar!

(6) Barretinho: Não:: tô querendo te comprar Sabrina! Pelo contrário... tô te oferecendo o que eu tenho de melhor, cara! O meu amor! Que nunca dei pra mulher nenhuma... Porque eu nunca amei ninguém! Sabrina, eu te amo pra caramba! Cara! Não joga isso fora, vai?!

(7) Sabrina: E se eu aceitasse? Quem me garante que você ia me respeitar? Nunca me respeitou! Quem me garante que eu não ia virar sua empregadinha de luxo?! Ficar cuidando de suas camisas... enquanto você galinha com as branquelas!

(8) Barretinho: Eu garanto... Eu garanto... Isso não vai acontecer... Sabrina, eu nunca mais tive uma mulher... Tô a oito meses... sem ter uma mulher... Eu quero você... Eu não quero a empregada, não... Eu quero a mulher da minha vida! Entende isso, cara!

(9) Sabrina: Isso não é amor, Barretinho; isso é obsessão! Também seja o que for, eu não quero saber de você.... Eu não vou ser sua mulher... Eu não vou me casar com você... Entendeu? Paulo de Barreto Filho?

(10) Barretinho: Por que não? Por que não? Por que eu não sou bom? É isso? Não sou bom o suficiente, eu sou pouco pra você? É isso que você tá querendo me dizer?

(11) Sabrina: Porque você é branco! Branco! Branco demais pra mim! Porque eu não gosto da tua cor! Homem pra mim tem que ser da raça! Quanto mais escuro, melhor! E não adianta fazer bronzeamento artificial... Fica com essa cor ridícula! ((risos)) Eu quero um homem negro! Que vai me dar filhos negros! Deus me livre aguar o meu sangue com uma coisinha branca que nem você... Fora, Barretinho! Fora da minha vida! Me deixa viver em paz! Larga do meu pé! Esquece! Esquece que eu existo! Sai da minha vida! E me deixa! Me deixa viver em paz!

(12) Barretinho: Não dá pra esquecer que você existe! Sem você minha vida não tem o menor sentido...

((Barretinho vai embora. O pai de Sabrina entra em cena, e diz para ela que tinha ouvido toda a discussão. A moça pergunta ao pai se ela não havia agido da maneira certa, e a resposta do pai é:)) 
(13) Pai de Sabrina (Celestino): Erradíssima, Sabrina! O que eu presenciei foi a pior manifestação de racismo que eu já vi na vida! Você sabe disso! Como eu sofri com isso na pele, filha! Discriminar o rapaz só porque é branco! Porque vai aguar o teu sangue! Você ficou maluca, Sabrina? Nossa, filha... pensa... Se isso fosse o contrário? Isso é coisa que se diga, filha. Eu não te criei assim...

(14) Sabrina: É por que eu achei que a gente nunca ia dar certo, pai! Nunca ia dar certo! Até pouquíssimo tempo, eu era a empregada que ele ficava burilando...

(15) Pai de Sabrina (Celestino): Eu sei, filha... Mas renegar a cor da pele é preconceito, é:: discriminação, filha...

((O pai de Sabrina pede para ela ir atrás de Barretinho e se desculpar pelo fato ocorrido. A moça segue as orientações do pai, e se depara com Barretinho, atravessando uma rua e, logo após, sendo atropelado por um carro.))

É válido lembrar que Barretinho pertence a uma família rica tradicional, mora na zona sul, etc. Enquanto Sabrina, por sua vez, mora no subúrbio, vem de uma família humilde e trabalha como doméstica. Buscando situar as personagens neste contexto narrativo, observe o QUADRO 4:

\section{QUADRO 4}

Novela Duas Caras - Caracterização dos personagens

\begin{tabular}{c|c|c|c|c}
\hline Personagens & Cor (Etnia) & Ambiente & Espaço & Participação \\
\hline Barretinho & Branca & $\begin{array}{c}\text { Classe Alta (Rico) } \\
\text { Boa conduta moral } \\
\text { Engraçado }\end{array}$ & Casa/Trabalho & Coadjuvante \\
\hline Sabrina & Negra & $\begin{array}{c}\text { Classe Baixa (Pobre) } \\
\text { Boa conduta moral } \\
\text { Boa pessoa / Agradável }\end{array}$ & $\begin{array}{c}\text { Casa da família } \\
\text { Barreto } \\
\text { Casa de Branca }\end{array}$ & Coadjuvante \\
\hline
\end{tabular}

Essas personagens circulam pelo mesmo espaço ficcional, mas são sujeitos com diferenças sociais visíveis. Contudo, mesmo diante dessa diversidade social, Barretinho se apaixona por Sabrina.

Nessa narrativa, Sabrina humilha o rapaz, como observa-se em sua fala (11): "Porque você é branco! [...] Branco demais pra mim! [...] não gosto da tua 
cor!"; e ela não aceita o pedido de casamento feito por Barretinho. Ela age de maneira preconceituosa para com Barretinho, como também mostrado em (11): "Deus me livre aguar o meu sangue com uma coisinha branca que nem você...". A valorização em relação ao branco nessa cena se inverte, aqui o sujeito branco não mais é modelo de referência para o 'mundo'.

Entretanto, Barretinho tenta a todo custo argumentar e convencer a moça do amor que ele sente, conforme mostrado pelos enunciados (1), (3), (4) e (6). Sendo assim, sua fala nos leva a inferir que:

(i) geralmente, ser uma doméstica negra é indício para ser explorada sexualmente, como apontado pelo enunciado (1): “[...] eu só queria levar a empregada gostosa pra cama...”

(ii) Barretinho crê que sua vida não terá mais sentido se Sabrina não se casar com ele, como mostrado em (3): "A minha vida não faz o menor sentido sem você do meu lado... cara.”

(iii) em (4), o personagem diz que Sabrina terá uma vida de rainha ao seu lado: "Casa comigo que eu vou te dar uma vida de rainha!"

(iv) as demais assertivas, como (8), (10) e (12), indicam a paixão ardente de Barretinho pela moça e sua vontade resoluta de se casar com ela e dedicarlhe o seu amor: "[...] eu quero você... eu não quero a empregada, não... eu quero a mulher da minha vida!"; "É isso? Não sou bom o suficiente, eu sou pouco pra você?"; "Sem você minha vida não tem o menor sentido..."

Nessas considerações, verifica-se emergirem os seguintes topö̈ desses encadeamentos argumentativos: 1) [+P]: SER MULATA $\rightarrow$ [+Q]: SER SEDUTORA; 2) $[+\mathrm{P}]:$ AMOR $\rightarrow[+\mathrm{Q}]:$ CASAMENTO.

Sendo que o primeiro topos pode se formalizar da maneira mostrada a seguir.

\section{QUADRO 5}

Exemplificação de Formas Tópicas

FT:

$[+\mathrm{P}]:$ ser mulata $\rightarrow[+\mathrm{Q}]$ : ser sensual

$[+\mathrm{P}]:$ ser mulata $\rightarrow[+\mathrm{Q}]:$ ser assediada sexualmente

Assim, as FTs acima se expressam na seguinte proposição: 
(i) Discurso: "No início era isso mesmo, eu só queria dar uns pegas! Eu confesso... que eu só queria levar a empregada gostosa pra cama... $[+\mathrm{P}]:$ :[...] a empregada gostosa...”

$[+\mathrm{Q}]$ : "No início, era isso mesmo, eu só queria dar uns pegas!" "Eu confesso... que eu só queria levar pra cama..."

(FT: $[+\mathrm{P}]:$ ser mulata $\rightarrow[+\mathrm{Q}]:$ ser assediada sexualmente)

Sob esses apontamentos, o topos $[+\mathrm{P}]:$ SER MULATA $\rightarrow[+\mathrm{Q}]:$ SER SEDUTORA revela que a personagem negra pode ser apresentada tanto pela telenovela quanto pelo cinema sob o arquétipo de "mulata boazuda" ou musa (RODRIGUES, 2001). Nesse sentido, observa-se que o padrão de mulher trazido por Sabrina nessa trama caracteriza-se pela sensualidade corporal da mulher negra, aquela que normalmente realiza as fantasias criadas pelo branco / patrão, ou seja, apresenta um apelo sexual. Logo, este topos emerge sob uma condição extrínseca, se inscreve a partir das representações socioculturais:

TOPOS EXTRÍNSECO $\rightarrow$ razões socioculturais: decorrente do contexto enunciativo - a condição de negra / mulata e empregada carrega uma representação simbólica evidenciada pela sensualidade do sujeito negro(a).

Já o segundo topos: $[+\mathrm{P}]:$ AMOR $\rightarrow[+\mathrm{Q}]:$ CASAMENTO indica as formas tópicas:

\section{QUADRO 6}

Exemplificação de Formas Tópicas

FT:

$[+\mathrm{P}]:$ ter amor $\rightarrow[+\mathrm{Q}]:$ querer casar em instituiçōes convencionais

$[+\mathrm{P}]:$ querer casamento $\rightarrow[+\mathrm{Q}]:$ ter vida de rainha

Sendo que as FTs retratadas no QUADRO 6 validam-se da seguinte forma:

(i) Discurso: “[...] eu tô te pedindo pra ser minha mulher pro resto da vida... quero casar contigo, de papel passado... na igreja... você quer prova de amor maior que essa?

$[+\mathrm{P}]:$ “[...] você quer prova de amor maior que essa?” 
[+Q]: "[...] eu tô te pedindo pra ser minha mulher pro resto da vida... quero casar contigo, de papel passado... na igreja [...]"

(FT: $[+\mathrm{P}]:$ ter amor $\rightarrow[+\mathrm{Q}]:$ querer casar em instituiçōes convencionais)

(ii) Discurso: "Mas é exatamente isso que eu tô te falando, Sabrina. Eu quero te dar outra vida... Casa comigo, que eu vou te dar uma vida de rainha!" $[+\mathrm{P}]:$ : $[\ldots .$.$] Casa comigo [\ldots]$ "

$[+\mathrm{Q}]:$ : "[...] que eu vou te dar uma vida de rainha!" Mas é exatamente isso que eu tô te falando, Sabrina. Eu quero te dar outra vida [...]"

$(\mathrm{FT}:[+\mathrm{P}]:$ querer casamento $\rightarrow[+\mathrm{Q}]$ : ter vida de rainha)

Desse modo, o topos apresentado revela-se a partir de um conhecimento cristalizado pelo imaginário social brasileiro acerca de determinadas convençôes sociais e culturais, que se assumem sob condiçōes extrínsecas. Observe a forma esquemática:

TOPOS EXTRÍNSECO $\rightarrow$ razões socioculturais: ocorre em função do contexto enunciativo, mostrando a representação do casamento / amor consolidado pela instituição igreja, e que o casamento / amor, acompanhado de uma boa situação financeira, implica mudança de vida para o casal.

Esse contexto discursivo, apresentado por Barretinho, sugere uma tentativa do sujeito comunicante (o autor) de contornar o fator racial, e essa possibilidade interpretativa ocorre devido à relação que poderá se institucionalizar pelo casamento entre etnias diferentes - Barretinho está apaixonado por Sabrina (a empregada doméstica negra) e quer a todo custo casar-se com ela, como notase em (1): "Eu me apaixonei de verdade por você, Sabrina... eu tô falando a verdade!"

Assim, o topos [+P]: AMOR $\rightarrow[+\mathrm{Q}]$ : CASAMENTO indica que o amor rompe com os tabus e, de certo modo, sacraliza convencionalmente um casal, como visto na fala de Barretinho em (1): "[...] eu tô te pedindo pra ser minha mulher pro resto da vida... quero casar contigo, de papel passado... na igreja... você quer prova de amor maior que essa?" sendo, então, um modo de transpor a barreira das diferenças desse âmbito narrativo - uma possível solução encontrada pelo autor para a questão racial existente entre o casal. 
Sabrina, por sua vez, não se convence da paixão de Barretinho por ela e, em sua fala, encontramos os seguintes argumentos:

(i) nos enunciados (2) e (7), a personagem deixa claro que não acredita nas boas intençóes expressadas por Barretinho, e, assim, ela refuta os argumentos do rapaz, como se pode notar respectivamente em: "O teu problema, Barretinho, é que você não aceita perder... eu não quis... aí, você cismou... ficou com a idéia fixa..."; "[...] E se eu aceitasse? Quem me garante que você ia me respeitar? Nunca me respeitou! Quem me garante que eu não ia virar sua empregadinha de luxo?! Ficar cuidando de suas camisas... enquanto você galinha com as branquelas!"

(ii) em (9), a moça recusa de forma veemente a proposta de casamento feita por Barretinho: "Isso não é amor Barretinho, isso é obsessão! [...] não quero saber de você [...] não vou ser sua mulher..."

(iii) Sabrina, em (11), expõe toda a sua raiva e o motivo para a recusa de tal pedido de Barretinho: "Porque você é branco! [...] não gosto da tua cor! Homem pra mim tem que ser da raça! [...] Eu quero um homem negro! Que vai me dar filhos negros! Deus me livre aguar o meu sangue com uma coisinha branca que nem você..."

Diante desses apontamentos, o topos convocado pelas assertivas dessa personagem nos indica: [+P]: BRANCO $\rightarrow[-\mathrm{Q}]:$ ACEITO, que se formaliza como mostrado abaixo, observe:

\section{QUADRO7}

Exemplificação de Formas Tópicas

\section{FT:}

$[+\mathrm{P}]:$ ser branco $\rightarrow[+\mathrm{Q}]:$ ser feio

$[+\mathrm{P}]:$ ser branco $\rightarrow[-\mathrm{Q}]$ : ser viril

$[+\mathrm{P}]:$ ser branco $\rightarrow[-\mathrm{Q}]:$ ter raça

$[+\mathrm{P}]:$ ser branco $\rightarrow[+\mathrm{Q}]:$ ter cor indesejável

As FTs acima se legitimam por meio das assertivas:

(i) Discurso: "Porque você é branco! Branco! Branco demais pra mim! Porque eu não gosto da tua cor!" 
[+P]: "Porque você é branco! Branco! Branco demais pra mim!"

[-Q]: “[...] Porque eu não gosto da tua cor!”

$($ FT: $[+\mathrm{P}]:$ ser branco $\rightarrow[+\mathrm{Q}]:$ ser feio $)$

(ii) Discurso: "Homem pra mim tem que ser da raça! Quanto mais escuro, melhor!”

[- P]: "Quanto mais escuro, melhor!"

$[+\mathrm{Q}]:$ "Homem pra mim tem que ser da raça!"

$(\mathrm{FT}:[+\mathrm{P}]:$ ser branco $\rightarrow[-\mathrm{Q}]:$ ter raça $)$

(iii) Discurso: "Quanto mais escuro, melhor! E não adianta fazer bronzeamento artificial... fica com essa cor ridícula!"

[-P]: "Quanto mais escuro, melhor!”

[+Q]: “E não adianta fazer bronzeamento artificial...” “[...] fica com essa cor ridícula!"

$($ FT: $[+\mathrm{P}]:$ ser branco $\rightarrow[-\mathrm{Q}]:$ ter cor indesejável)

O personagem Barretinho acredita que, ao fazer bronzeamento artificial, ele irá despertar a atenção de Sabrina, e até mesmo seduzir a moça, afinal ela diz gostar de homens negros. Sendo assim, o topos evocado revela-se sob o caráter extrínseco dos encadeamentos linguísticos em questão, representado através do universo sociocultural. Veja o esquema abaixo:

TOPOS EXTRÍNSECO $\rightarrow$ razões sócio-culturais: o contexto narrativo revela uma representação acerca do homem branco como um sujeito discriminado.

Os valores entre branco / negro nesse instante se invertem, as designações realizadas por Sabrina em relação à Barretinho nos mostram que ela reage de maneira pouco usual, no sentido de não aceitar a proposta de casamento do rapaz, e ainda tratá-lo como se ele fosse o "diferente".

Todavia, o proferimento realizado por Celestino (pai de Sabrina) em relação ao comportamento da moça, como mostrado pelas assertivas (13) e (15), busca contornar a manifestação racista explicitada pela filha: 
(i) a repreensão do pai de Sabrina por sua atitude discriminatória é vista em (13): “[...] eu presenciei foi a pior manifestação de racismo que eu já vi na vida! Você se sabe disso! Como eu sofri com isso na pele, filha! [...]"

(ii) O enunciado (15) indica o bom senso e / ou sensatez por parte desse personagem, afinal, como ele mesmo diz: "renegar a cor da pele é preconceito".

Assim, por esse contexto, percebe-se emergir mais um topos: $[+\mathrm{P}]$ : RENEGAR A COR DA PELE $\rightarrow[+Q]$ : TER PRECONCEITO, que se formaliza da seguinte maneira:

\section{QUADRO 8}

Exemplificação de Formas Tópicas

FT:

$[+\mathrm{P}]:$ ser branco e / ou negro $\rightarrow[+\mathrm{Q}]:$ ter igualdade racial / social

As FTs mostradas acima se validam da seguinte maneira:

(i) Discurso: "O que eu presenciei foi a pior manifestação de racismo que eu já vi na vida! [...] Discriminar o rapaz só porque é branco! Porque vai aguar o teu sangue!"

[+P]: “[...] Discriminar o rapaz só porque é branco!

[-Q]: "O que eu presenciei foi a pior manifestação de racismo que eu já vi na vida!"

$($ FT: $[+P]:$ ser branco $\rightarrow[+\mathrm{Q}]:$ ter igualdade racial / social $)$

(ii) Discurso: “[...] renegar a cor da pele é preconceito... é discriminação, filha..."

$[+\mathrm{P}]:$ “[...] renegar a cor da pele é preconceito...

[+Q]: “[...] é discriminação, filha...”

$($ FT: $[+\mathrm{P}]:$ ser negro $\rightarrow[+\mathrm{Q}]:$ ter igualdade racial / social $)$

Novamente, um topos extrínseco é manifestado, pois surge em decorrência das reproduções sociocognitivas culturais, observe: 
topos extrínseco: razões socioculturais: o plano enunciativo mostra que não interessa a cor da pele, não se deve discriminar o ser humano, assim, tanto o branco como o negro devem ter igualdade social e racial.

Desse modo, o personagem Celestino (pai de Sabrina), em suas afirmações, busca contornar a manifestação racista conduzida pelo discurso de sua filha, e, como verificado pela narrativa, ele parece conseguir esse feito. Logo, o topos criado pelo enunciado desse personagem refuta o topos racista, oriundo das assertivas da personagem Sabrina, podendo ser caracterizado sob um teor anti-racista.

Nas cenas analisadas, portanto, nos deparamos com topoï direcionados à questão do preconceito racial e social. As enunciações analisadas não apenas apresentam componentes linguísticos que remetem a um conhecimento que se perpetua ao longo do tempo no universo social brasileiro, no qual o indivíduo negro e / ou pobre é nitidamente discriminado, mas também refletem uma discriminação ao avesso - agora é o negro que não aceita a 'brancura' como algo comum.

Assim, a cena da telenovela $O$ Profeta revela um preconceito em relação à "cor" do sujeito, à condição sociofinanceira desse indivíduo, além da negação de etnia. Nessa trama, o ser branco é visto como superior. No episódio de Duas Caras, o preconceito assume outra forma, a da discriminação do negro para com o branco. Os papéis, nessa instância, são invertidos.

Percebe-se, apenas em uma das narrativas, um personagem atestando o discurso não preconceituoso, como se pode notar em Duas Caras. Nesse contexto, o pai de Sabrina tenta contornar o racismo praticado pela filha, com seu proferimento apaziguador.

No quadro abaixo, procuramos caracterizar os topö̈ encontrados por esta investigação, salientando, somente, o ponto de vista dessas tramas em relação à pessoa negra.

Por conseguinte, em O profeta teremos: 


\section{QUADRO $9^{14}$}

Topöi relacionados ao preconceito racial

Cena da novela: O Profeta

Topos Geral: Quanto mais ser negra e empregada tanto mais ser discriminado

\begin{tabular}{l|l}
\hline FT reprodutor & $\begin{array}{l}{[\mathrm{Qma}] \text { ser negro }[\text { Tma }] \text { ser inferior }} \\
{[\mathrm{Qma}] \text { ser negro }[\text { Tma }] \text { negar a etnia }} \\
{[\mathrm{Qma}] \text { ser negra e doméstica }[\text { Tme] ter bons tratamentos }} \\
{[\mathrm{Qma}] \text { ser negra e doméstica }[\text { Tma] comer na cozinha }}\end{array}$ \\
\hline FT desconstrutor & $\varnothing$ \\
\hline FT mascarador & $\varnothing$ \\
\hline
\end{tabular}

Por meio desse quadro observamos as formas tópicas que reproduzem o preconceito racial (FT reprodutor) instaurado nessa cena, assim como a forma tópica que desconstrói (FT descontrutor) e a que mascara a questão racial (FT mascarador). Pelo que se pode notar, porém, apenas a 'FT reprodutor' se destaca, enquanto as demais não apresentam nenhuma novidade.

Já em Duas Caras, encontraremos:

$$
\text { QUADRO } 10
$$

Topöi relacionados ao preconceito racial

Cena da novela: Duas Caras

Topos Geral: Quanto mais ser branco tanto menos aceito

\begin{tabular}{l|l}
\hline FT reprodutor & $\begin{array}{l}{[\mathrm{Qma}] \text { ser branco }[\mathrm{Tma}] \text { ser feio }} \\
{[\mathrm{Qma}] \text { ser branco }[\mathrm{Tme}] \text { ser viril }} \\
{[\mathrm{Qma}] \text { ser branco }[\mathrm{Tme}] \text { ter raça }} \\
{[\mathrm{Qma}] \text { ser branco }[\mathrm{Tma}] \text { ter cor indesejável }}\end{array}$ \\
\hline FT desconstrutor & {$[\mathrm{Qma}]$ ser branco e / ou negro [Tma] ter igualdade racial / social } \\
\hline FT mascarador & $\varnothing$ \\
\hline
\end{tabular}

Nesse episódio percebemos algumas formas tópicas que reproduzem a racialização (FT reprodutor) e apenas uma que a desconstrói (FT desconstrutor). As formas tópicas do tipo mascarador não são perceptíveis nessa narrativa.

Dessa forma, para as formas tópicas que reproduzem a racialização, temos: quanto mais ser branco tanto mais ser feio; quanto mais ser branco tanto menos 
ser viril; quanto mais ser branco tanto menos ter raça; quanto mais ser branco tanto mais ter cor indesejável. Já para aquelas que desconstroem verifica-se: quanto mais ser branco e / ou negro tanto mais ter igualdade racial / social.

A cena da novela $O$ Profeta tende a confirmar que as crenças negativas, arraigadas pela sociedade brasileira em relação ao negro, continuam. No episódio de Duas Caras, por sua vez, as vozes enunciativas se interpõem com argumentos que tendem a "chocar" as crenças partilhadas pelo público, pois não estamos acostumados a ver uma manifestação racista à maneira como foi encenada pela personagem Sabrina.

Araújo (2000) explica como as telenovelas brasileiras tentam conduzir suas tramas:

A telenovela pretende, hoje, representar a moderna sociedade brasileira, discutir temáticas sociais atuais e candentes; entretanto, não inclui nessas temáticas uma imagem mais moderna nem um questionamento mais sério e corajoso da questão racial e das relações entre brancos e negros no Brasil, a não ser por meio de algumas tentativas esporádicas e realizadas freqüentemente, com alguns equívocos (ARAÚJO, 2000, p. 13-14).

Nesse sentido, as duas cenas das telenovelas analisadas mostram as relaçōes interétnicas em nossa sociedade, cada qual em seu contexto. Porém, a narrativa de O Profeta parece ratificar a existência do preconceito racial e social, enquanto Duas Caras busca mascarar essa questão, sob uma racialização ao avesso.

Portanto, nos episódios investigados, percebemos topöi sendo evocados pelo princípio da universalidade, generalidade e gradiência. Contudo, esses topöi parecem surgir, basicamente, através de um topos geral: a racialização (processo no qual o negro admite / manifesta o racismo). Desse modo, os topö̈, quando evocados, são admitidos e aceitos socialmente, além de se apresentarem como um modo de estruturar os significados em questão, enquanto as FTs agem como 'regras de ações', isto é, são realizações discursivas.

\section{Considerações finais}

A noção de topos, como se pode notar, apontou o senso comum discriminatório a partir dos registros discursivos projetados pelas cenas das 
tramas de O Profeta e Duas Caras, além das possíveis soluções para desconstruir e / ou mascarar essa questão.

Por essas telenovelas, observa-se que o preconceito racial existe e está presente nas narrativas, entretanto sob pontos de vista distintos, pois cada uma dessas tramas intenciona um público específico - daí o enredo focado pelas narrativas sobre a questão do racismo ser diferente.

A discriminação entre etnias decorrente dessas tramas é mostrada de forma explícita, ratificando as diferenças entre negros e brancos. E ainda, promove a superioridade branca, estabelecendo o conflito interétnico. Este preconceito surge sob a emblemática da 'cor', assim como do 'dinheiro' - quanto mais preto e pobre o sujeito for, maior será sua exclusão social.

Sob essa ótica, Paiva (1998) afirma que: "o negro, ainda hoje, é visto por muitos, como demônio familiar. As empregadas domésticas, principalmente as negras, são livres, mas não penetram no seio das famílias e nem utilizam os elevadores sociais". Essa colocação feita por Paiva (1998) pode perfeitamente legitimar a construção da narrativa $O$ Profeta. A personagem Natália não consegue ver o sujeito de "cor" como alguém normal, e sim como o diferente.

Desse modo, nota-se que o racismo verificado nessa narrativa não se vincula apenas às considerações biológicas, ${ }^{15}$ ele é exercido também em função da 'cor', numa transição gradual: quanto mais distante da cor negra, menor a discriminação, e isso prevalece também para uma situação contrária a essa.

Em Duas Caras é visível a construção de personagens cujo objetivo se faz de modo a contornar a existência do preconceito, como se percebe com o pai de Sabrina, que intentará quebrar a corrente discriminatória. Logo, nota-se que esta novela, a princípio, pretende abrir a discussão sobre o racismo e busca alcançar um público diferente daquele de $O$ Profeta - seu horário de exibição éàs $21 \mathrm{~h}$ - cujo público pressupõe possuir um senso critico mais apurado para discutir temas de forma mais democrática, como o da racialização, mas o interessante é que ela não consegue sair dos estereótipos a partir dos quais a sociedade brasileira aborda a questão racial.

A racialidade incutida nessas tramas, a princípio, tenta quebrar a corrente do preconceito racial. No entanto, acaba cometendo os mesmos erros advindos do meio social - deixa de lado o que é importante para combater o racismo e investe no conflito entre casais, famílias, colegas de escola ou coisas do tipo, e ainda acentua os estereótipos negativos sobre os negros. 
Ambas as novelas, portanto, reproduzem a discriminação que os indivíduos negros podem vir a sofrer numa dada sociedade, mas claro que cada telenovela o faz à sua maneira, em razão de enredos diferenciados.

\section{Notas}

${ }^{1}$ MARCUSCHI, Antônio Luiz. Análise da conversação. 5. ed. São Paulo: Ática, 2005. Cap. 2, p. $14-16$.

${ }^{2}$ Cf. Portal Teledramaturgia. Disponível em: <http://www.teledramaturgia.com.br/ alfabetica.htm> Acesso em: 22 ago. 2007.

${ }^{3}$ A trama foi escrita por Duca Rachid, Thelma Guedes e Júlio Fischer, com colaboração de André Ryoki, Theresa Falcão e Alessandro Marson, com supervisão textual de Walcyr Carrasco, direção de Vinicius Coimbra e Alexandra Boury e, finalmente, direção geral de Mário Márcio Bandarra (núcleo Roberto Talma).

${ }^{4} \mathrm{Cf}$. <http://www.teledramaturgia.com.br/alfabetica.htm> Acesso em: 26 jun. 2008.

${ }^{5}$ Além desse autor, Duas Caras teve a colaboração de Gloria Barreto, Izabel de Oliveira, Maria Elisa Berredo, Filipe Miguez, Nelson Nadotti, Sergio Goldenberg, com direção de Claudio Boeckel, Ary Coslov, Gustavo Fernandes, sob Direção Geral de Wolf Maya - Núcleo: Wolf Maya e cenografia de Ana Maria Mello, Marcelo Carneiro, Maurício Holfs, Kaka Monteiro. Disponível em: <http://www.teledramaturgia.com.br/ alfabetica.htm>. Acesso em: 26 jun. 2008.

${ }^{6}$ DUCROT. Topoü e formas tópicas. In: ZANDWAIS, Ana (Org.). Relações entre pragmática e enuncią̧ão. Porto Alegre: Sagra Luzzatto, 2002. Cap.1, p.10-21.

7 Em Ducrot (1989).

${ }^{8}$ O pressuposto, segundo Ducrot (1987, p. 20), procura "sempre situar-se em um passado do conhecimento, eventualmente fictício, ao qual o locutor parece referir-se" (DUCROT, 1987, p. 20).

9 Esta cena denominada como: "A triste descoberta", e encontra-se em anexo.

${ }^{10}$ Por ambiente, entende-se o espaço vivido pelas personagens cujas peculiaridades são de ordem socioeconômica, moral, psicológica, podendo ser, então, compreendido como um conceito que aproxima tempo e espaço, "pois é a confluência destes dois referenciais, acrescido de um clima." (GANCHO, 1997, p. 23).

${ }^{11}$ Espaço, para Gancho (1997), é o lugar onde a ação narrativa acontece. A função principal do espaço é situar as açóes dos personagens, estabelecendo entre eles o processo interacional. Em suma, espaço designa o lugar físico onde se passa a narrativa. 
${ }^{12}$ Grifos nossos.

${ }^{13}$ Entende-se por clichê "um grupo de léxicos que demonstram julgamentos 'banais', “já vistos” (CHARAUDADEAU; MAINGUENEAU, 2006, p. 214).

${ }^{14}$ Legenda: CONVENÇÕES PARA FORMAS TÓPICAS

$\begin{array}{ll}\text { Operador } & \text { Símbolo } \\ \text { Quanto mais } & \text { Qma } \\ \text { Tanto mais } & \text { Tma } \\ \text { Quanto menos } & \text { Qme } \\ \text { Tanto menos } & \text { Tme }\end{array}$

${ }^{15}$ Distinções genéticas e biológicas, isto é, advindas da natureza.

\section{Referências}

ARAÚJO, Joel Zito. A negação do Brasil: o negro na telenovela brasileira, São Paulo: Senac, 2000.

CHABROL, Claude; EMEDIATO, Vander. A problemática da argumentação na língua, a teoria dos topoï e as representações intrínsecas e extrínsecas. In: MACHADO, Ida Lucia et alii. Ensaios em Análise do Discurso. Belo Horizonte: FALE / UFMG, 2002. p. 295-315.

CHARAUDEAU, Patrick; MAINGUENEAU, D. Dicionário de análise do discurso. São Paulo: Contexto, 2006.

DUCROT, O. Argumentação e topoï argumentativos. In: GUIMARÃES, E. (Org.). História e sentido na linguagem. Campinas: Pontes, 1989. p.13-38.

DUCROT, O. O dizer e o dito. Campinas: Pontes, 1987.

DUCROT, O. Os topoï na Teoria da Argumentação na Língua. Revista Brasileira de Letras, São Carlos, v. 1, n. 1, p. 1-11, 1999.

DUCROT, O . Topoï e formas tópicas. In: ZANDWAIS, Ana (Org.). Relaçôes entre pragmática e enunciação. Porto Alegre: Sagra Luzzatto, 2002. Cap.1, p.10-21.

GANCHO. Cândida Vilares. Como analisar narrativas. 4. ed. Série Princípios. São Paulo: Editora Ática, 1997.

MARCUSCHI, Antônio Luiz. Análise da conversação. 5. ed. São Paulo: Ática, 2005. Cap. 2, p. $14-16$.

MARI, Hugo. A promessa como ato de fala: suas implicações no discurso. Geraes Revista da Comunicação Social, n. 48, p. 34-41, jul. 1997. 
PAIVA, V. L. M. O. Metáforas Negras. In: PAIVA, V. L. M. O. (Org.). Metáforas do Cotidiano. Belo Horizonte: UFMG, 1998. p. 105-119. Parâmetros Curriculares Nacionais. Secretaria de Educação. Brasília, 1998.

PORTAL Teledramaturgia. 2007. Disponível em: <http://www.teledramaturgia.com. br/alfabetica.htm>. Acesso em: 22 ago. 2007.

RODRIGUES, João Carlos. O negro brasileiro e o cinema. Rio de Janeiro: Pallas, 2001.

SILVA, Adriana dos Reis. A construção da personagem afro-descendente na telenovela brasileira sob uma perspectiva discursiva. 2009.142f. Dissertação (Mestrado em Linguística e Língua Portuguesa) - Pontifícia Universidade Católica de Minas Gerais, Belo Horizonte, 2009. 


\section{ANEXO}

\section{Cena: "A triste descoberta" - O Profeta (20/12/2006)}

(1) Dedé: Teresa, você viu a Natália?

(2) Teresa: De certo está no quarto da Analu...Vamos até lá?

(3) Dedé: Vamos!

((No momento em que Dedé e Tereza iam à procura de Natália, a noiva (Sônia) se aproxima e diz para as duas:))

(4) Sônia: Onde vocês vão?

(5) Dedé: Procurar a Natália pra ir embora... O dono da casa não quer a gente aqui... Você viu o que ele fez... Mandou a Rúbia e todo pessoal dela ir embora...

(6) Sônia: Quê?! Não! Deve te havido algum mal entendido... O Clóvis é um homem bom... Gentil... Honesto...

(7) Teresa: Não, Sônia! Se fosse, não teria mandado a Dedé ficar na cozinha no dia do seu casamento... Esse homem tem uma pedra no lugar do coração... Ah! Eu só sinto por você, querida... Eu sinto muito. Eu já volto.

((Teresa dá um beijo em seu namorado e sai com Dedé para procurar Natália. Sônia fica perplexa com a fala de Teresa. Neste instante, Natália está no quarto de Analu contando histórias para ela. Dedé e Teresa se aproximam do quarto, a porta esta aberta e elas escutam a conversa das meninas.))

(8) Natália: Mamãe faz questão de me levar pra França, Analu. Um lugar que faz bastante neve, sabe? Bem que eu prefiro a praia, mas ela não gosta do sol... Acho que é por causa da pele dela que é branquinha... branquinha...

(9) Dedé: Teresa... Você viu! A Natália tem vergonha de mim! 